\title{
PATHOGENICITY OF Blastocystis sp. TO THE GASTROINTESTINAL TRACT OF MICE: RELATIONSHIP BETWEEN INOCULUM SIZE AND PERIOD OF INFECTION
}

\author{
Mariana F. PAVANELLI(1), Edilson Nobuyoshi KANESHIMA(2), Carla F. UDA(3), Cristiane M. COLLI(3), \\ Ana L. FALAVIGNA-GUILHERME(3) \& Mônica L. GOMES(3)
}

\begin{abstract}
SUMMARY
The pathogenic potential of Blastocystis sp. in experimental models requires further investigation. In this work, the pathogenicity of this parasite in the gastrointestinal tract of male Swiss mice was evaluated according to the inoculum size and period of infection. Animals were infected intragastrically, with 100, 500, 1,000, 5,000 and 10,000 Blastocystis sp. vacuolar forms obtained from a mixture of eight human isolates cultured axenically in Jones' medium. After seven, 14, 21, 28 and 60 days of infection, the animals were sacrificed and fragments of the small intestine (duodenum), large intestine, and cecum were subjected to histopathological analysis. Blastocystis sp. triggered an inflammatory response in the different tissues analyzed, with a predominance of mononuclear cells. The parasite was found in the muscular layer of the cecum, showing its invasive character. Larger inocula triggered inflammatory processes earlier (seven days) than smaller ones (from 21 days). We conclude that, in the proposed model, the pathogenicity of Blastocystis sp. isolates that were studied is related to inoculum size and period of infection.
\end{abstract}

KEYWORDS: Blastocystis; Pathogenicity; Mice; Inoculum; Period of infection.

\section{INTRODUCTION}

Blastocystis sp. is the etiological agent of blastocystosis, which is one of the most prevalent intestinal protist parasites found in humans ${ }^{7,8,15,16}$. Its distribution is worldwide, with prevalence rates exceeding $50 \%$ in developing countries, especially those in tropical and subtropical regions ${ }^{1,5,21}$. Higher disease percentages are related to poor hygiene, contact with pets, overcrowding, consumption of contaminated food and water, lack of sanitation and waste disposal ${ }^{18,21}$.

Blastocystosis can affect children and adults. Several authors ${ }^{1,3,5,18,19,24}$ consider Blastocystis sp. pathogenic, unlike others ${ }^{7,8}$ who consider it as nonpathogenic due to the occurrence of many asymptomatic cases ${ }^{8}$. However, secondary syndromes, such as hives, have been reported due to the presence of this protist ${ }^{24}$. Various factors can influence the pathogenicity of Blastocystis, including genetic subtype ${ }^{7}$, stage of development ${ }^{22}$, quantity of parasitic forms ${ }^{20}$, immune status and genetics of the host ${ }^{13}$, intervention therapy and concomitant infection by other parasites ${ }^{14}$.

In several animal models, the infectivity of cystic forms, histopathological changes caused by Blastocystis sp. and tissue predilection were investigated ${ }^{5,23,26}$. There are no reported studies of histopathogenicity of Blastocystis sp. comparing different inocula and periods of infection in a murine model. To address this issue, the pathogenicity of Blastocystis sp. in the intestinal tracts of Swiss mice orally infected with different inoculum sizes and periods of infection was investigated.

\section{MATERIAL AND METHODS}

Parasites: Vacuolar forms of Blastocystis sp. were obtained from stool samples of patients who live in northwestern Parana, southern Brazil, screened at the Food and Environmental Parasitology Laboratory of the State University of Maringa (Laboratório de Parasitologia Ambiental e de Alimentos da Universidade Estadual de Maringá (LPAA/ UEM), using the Hoffman, Pons and Janer (HPJ) technique ${ }^{6}$, which was modified with $0.85 \%$ saline solution.

Eight samples of Blastocystis sp. belonging to subtypes 1 and 3 were seeded in Jones medium ${ }^{15}$, and the axenic cultures were maintained at $37{ }^{\circ} \mathrm{C}$ under anaerobic conditions, agitated daily according to IRIKOV et al. $(2009)^{10}$. After 72 hours, the cultures were examined on a 40x objective to confirm the growth and determination of inoculum.

A large number of vacuolar forms were necessary for standardization of the inocula, and cultures of the eight samples were mixed. The parasitic forms were centrifuged at 1,190 $\mathrm{g}$ for 10 minutes, and the pellet was resuspended in phosphate buffered saline (PBS) $\mathrm{pH}$ 7.4. The vacuolar forms were counted in a Neubauer chamber for preparation of inocula containing $10,000,5,000,1,000,500$ and 100 parasites.

(1) Universidade Estadual de Maringá, Programa de Pós Graduação em Ciências da Saúde. Maringá, PR; Faculdade Integrado de Campo Mourão, Campo Mourão, Paraná, Brasil. (2) Universidade Estadual de Maringá, Laboratório de Patologia, Departamento de Ciências Básicas da Saúde, Maringá, PR, Brasil.

(3) Universidade Estadual de Maringá, Laboratório de Parasitologia Ambiental e de Alimentos DBS/UEM, Maringá, PR, Brasil.

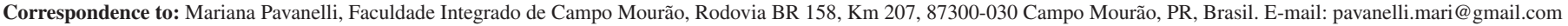




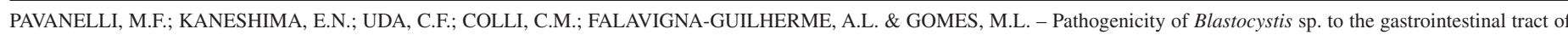
mice: relationship between inoculum size and period of infection. Rev. Inst. Med. Trop. Sao Paulo, 57(6): 467-72, 2015.

Maintenance, infection and animal sacrifice: In this exploratory study, we used 30 male Swiss mice, which were immunocompetent at 21 days of age. The animals were purchased from the Central Vivarium of the Universidade Estadual de Maringá (UEM) and were kept in an animal facility biotery of the Parasitology Laboratory/UEM in polypropylene boxes (size 414 x 344 x $168 \mathrm{~mm}$ ) capped with galvanized grids with a central depression for the deposition of feed (commercial) and water bottles (chlorinated), which were at the animals' disposal. The boxes remained in an air-conditioned environment (temperature between 21 and $23{ }^{\circ} \mathrm{C}$ ) with a 12-hour light/dark cycle. Prior to infection, the fecal material of animals was analyzed by the HPJ technique ${ }^{6}$ to confirm the absence of enteric parasites.

For infection, the animals were distributed into six groups, five experimental and one control (G1, G2, G3, G4, G5 and CN - Negative control). Each group contained five animals that were housed together. The animals of groups G1 to G5 were infected with 10,000, 5,000, 1,000, 500 and 100 vacuolar forms, respectively. The $\mathrm{CN}$ group received only saline solution in the corresponding volume of the challenged groups, and it was kept in the same conditions. The animals were infected intragastrically, with the aid of a gavage cannula, with vacuolar forms which have a large central vacuole and some surrounding granules.

Starting two days after infection, the animals were monitored weekly by collecting their feces, which were evaluated by the HPJ technique ${ }^{6}$. The observation of characteristic small, ovoid or spherical cystic forms with a multilayered wall confirmed the parasite presence. A molecular method was also used to confirm the infection. The small subunit of ribosomal RNA gene was amplified using RD3 and RD5 primers according to DOMÍNGUEZ-MARQUEZ et al. (2009) ${ }^{3}$. The negative animals were examined every two days until infection was confirmed.

From the date of infection, each week, one animal from each group was euthanized making a total of 20 animals in four weeks. The five other animals were sacrificed on the sixtieth day of infection. On the day of sacrifice, the fecal parasitological exams of the animals showed positive results for Blastocystis sp., and fragments of the small intestine (duodenum), cecum and large intestine (proximal colon) were collected to perform histopathological analyses according to HUSSEIN et al. $(2008)^{7}$.

Preparation of histological tissue: The tissue fragments were cut lengthwise and washed with $0.85 \%$ saline solution. Then, they were fixed, opened in $10 \%$ formalin solution and preserved in $70 \%$ alcohol. After tissue fixation, the pieces were dehydrated, diaphonized and embedded in paraffin. For these processes, the pieces were immersed in alcohol solutions with increasing percentages (80, 90 and 100\%), then in a solution of xylol and absolute alcohol (1:1) and finally in xylol (the pieces were immersed for a period from 10 to 20 minutes).

After embedding in paraffin, $5 \mu \mathrm{m}$ thick sections were obtained using a microtome, separated by $20 \mu \mathrm{m}$ intervals (semi-serial cuts). The prepared slides were stained with hematoxylin-eosin and the coverslips were fixed with Permount ${ }^{\circledR}$ solution.

Histopathological analysis: The microscopic preparations were analyzed with a 40x objective and when it was necessary with a $100 \mathrm{x}$ objective. The reading was performed twice (cuts A and B) and each cut was $40 \mu \mathrm{m}$ along from the next one. The whole intestinal circumference was examined, and the parasite and/or inflammatory reactions were quantified.

The inflammatory process was defined by visualization of leukocytes (small size [small cytoplasm and large nucleus] and basophilic staining, which differentiate them from other cells such as enterocytes, goblet cells and $\mathrm{M}$ cells). In tissues, the initiation of the inflammatory process was identified by agglomeration of these cells and ended by visualization of the normal tissue standard.

Statistical analysis: The comparison of the results was performed with the $\mathrm{Z}$ test using the Statistica software version 8.0 and for independent samples was performed using the Student's t-test and Microsoft Excel 2007 software. For the main histopathological results, a descriptive statistical analysis was performed using Microsoft Excel 2007 software.

Ethical aspects: This study was approved by the Ethics Committee of the Use of Animals in Experimentation of the State University of Maringa (Comitê de Conduta Ética no uso de Animais em Experimentação CEAE) under the number 081/2011 and the Standing Committee on Ethics in Research Involving Humans of the State University of Maringa (Comitê Permanente de Ética em Pesquisa (COPEP) envolvendo Seres Humanos) under the number 439/2009.

\section{RESULTS}

Infectivity of vacuolar forms of Blastocystis sp. in Swiss mice: The different proposed inocula (100 to 10,000) were sufficient to cause infections in the animals. From the second day of infection, vacuolar forms of the parasite were observed in 60\% (15/25) of the animals, different from those administered intragastrically, indicating the development of the parasite within the intestinal wall. In $40 \%(10 / 25)$ of the animals that still showed negative parasitological tests and which were monitored every two days, the infection was confirmed until the seventh day after administration of the vacuolar forms.

Tissular predilection of Blastocystis sp.: Table 1 shows the distribution of the vacuolar forms of Blastocystis sp. that were found in the small intestine (duodenum), cecum and large intestine (proximal colon) of orally infected mice. When the proportion of parasites was observed in each portion of the gastrointestinal tract and it was compared ( $\mathrm{Z}$ test), no significant difference ( $p=0.0608$ and $p=0.1889$ ) was observed, however, a distinct predilection of the parasite for the cecum was noticed. Concerning the site of attachment of the parasite in the gut, it has been found in the mucosa and submucosa, invading the muscular layer of the large intestine (Fig. 1). Figure 1 shows part of a hyperplastic lymphoid aggregate, a vacuolar form of Blastocystis sp. in the muscle layer with peripheral granules and a central vacuole.

Relationship of histopathogenicity with inoculum and period of infection: Table 2 shows the relationship between the period of infection, inoculum and presence of vacuolar forms of Blastocystis $\mathrm{sp}$. in the intestinal tract of orally infected Swiss mice. The number of vacuolar forms was not influenced by the inoculum but was affected by the period of infection. The Student's t-test showed a statistically significant difference between the number of vacuolar forms that were recorded on the seventh (10) and sixtieth (0) days of infection $(p<0.05)$. 


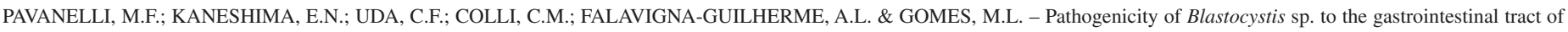
mice: relationship between inoculum size and period of infection. Rev. Inst. Med. Trop. Sao Paulo, 57(6): 467-72, 2015.

Table 1

The distribution of vacuolar forms of Blastocystis sp. found in the intestinal tract of orally infected mice

\begin{tabular}{lccc}
\hline Organ & $\mathrm{n}($ medium $) \pm \mathrm{S}$ & $\%$ & $p$-value* \\
\hline Duodenum & $8 \pm 0.69$ & 29.63 & 0.1889 \\
Cecum & $13 \pm 0.50$ & 48.15 & Reference \\
Large intestine & $6 \pm 0.52$ & 22.22 & 0.0608 \\
\hline
\end{tabular}

* $\mathrm{Z}$ test for proportion comparison.

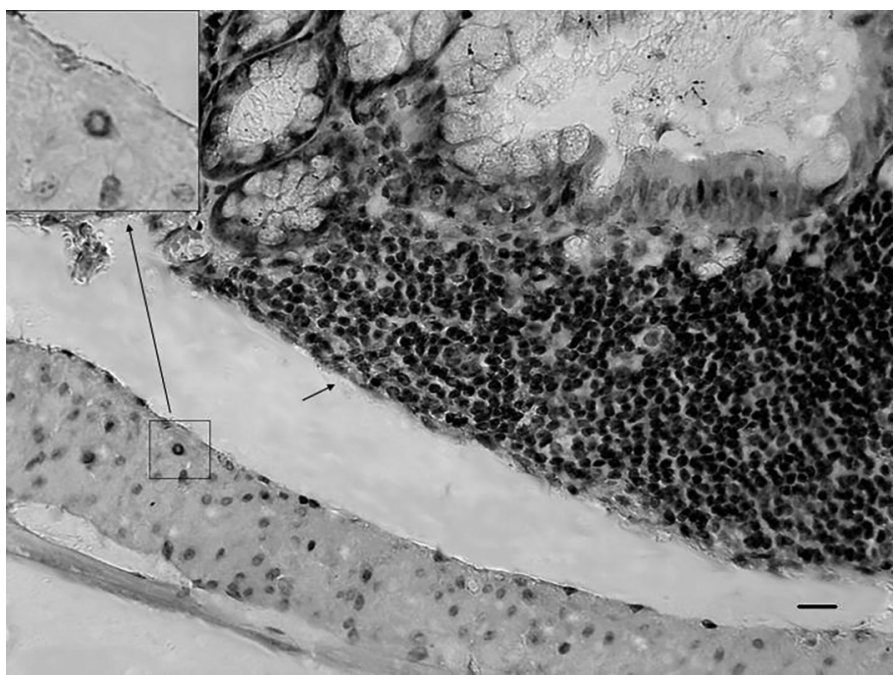

Fig. 1 - Portion of large intestine containing a part of hyperplastic lymphoid aggregate (small arrow) and a vacuolar form of Blastocystis sp. that were implanted in the muscle layer (upper left quadrant - larger arrow $\mathrm{H} \& \mathrm{E} 1,000 \mathrm{X}$ ) of the tissue $\mathrm{H} \& \mathrm{E} 40 \mathrm{X}$, in addition to the presence of peripheral beads and a central vacuole. Bar: $100 \mu \mathrm{m}$.

In the period between 14 and 28 days, the number of vacuolar forms ranged from three to eight, without significant differences.

The groups that were infected with 10,000 (G1) and 100 (G5) vacuolar forms showed inflammatory tissue in all periods of infection, but there were more in G1 (10) than in G5 (7) (Table 3). The difference between these two groups was not significant $(p=0.1954)$, but the results indicate that the inoculum influenced the inflammatory response and the course of infection. In the groups infected with other inocula (G2 to G4), the inflammatory processes ranged from four to eight and were more pronounced later (between 21 and 60 days after infection). The period of infection did not influence the inflammatory response.

Regarding the intensity of inflammation, only the mild type was observed on the sixtieth day of infection. Figure 2 shows leukocyte migration with a predominance of mononuclear cells and the presence of neutrophils and eosinophils among the polymorphonuclear cells. In response, the presence of the parasite was still observed in hyperemic vessels and hyperplastic lymphoid tissues. Signs of inflammation were observed only in sections where the vacuolar forms of Blastocystis sp. were being developed and the main changes were found in sections of the large intestine and cecum, the preferred regions of vacuolar forms of this parasite.

Analysis of different organs showed that the inflammatory processes were observed only at 21 days of infection in the duodenum. In the proximal colon of the large intestine, mild to moderate signs of inflammation were recorded during all periods of infection, highlighting that the vacuolar form of Blastocystis sp. implanted in the muscle layer only in this organ. Inflammatory processes in the cecum were observed from day 21 of infection.

Table 4 shows that the quantity of hyperplastic lymphoid tissue was influenced by both the inoculum and the period of infection. In G1 and G2 (larger inocula), 100\% of lymphoid aggregates were hyperplastic and the inflammatory processes occurred earlier (seven and 14 days). In G3, G4 and G5 (smaller inocula) from 33.3 to $100 \%$ of lymphoid tissue were hyperplastic with inflammatory processes occurring later (from the fourteenth day of infection), having a higher frequency between 21 and 28 days. It is noteworthy that on the fourteenth day only one animal showed $100 \%$ hyperplastic lymphoid tissues, and on the sixtieth day few signs of inflammation were found.

\section{DISCUSSION}

In this work, we observed that the pathogenicity of Blastocystis sp. in Swiss mice was related to inoculum size and period of infection. There were more inflammatory processes in animals that were infected with the largest inocula $(10,000)$, and these effects were observed during all periods of infection. For smaller inocula, the inflammatory processes occurred in fewer numbers and later during the infection period. In addition, the periods of infection assessed influenced the quantity of vacuolar forms implanted in the tissue and the percentage of hyperplastic lymphoid tissue. This is the first report showing the relationship

Table 2

Relationship between the period of infection, inoculum and presence of vacuolar forms of Blastocystis sp. in the intestinal tract of orally infected Swiss mice

\begin{tabular}{|c|c|c|c|c|c|}
\hline Period of infection (days) & $7 *$ & 14 & 21 & 28 & 60 \\
\hline Group/Inoculum (vacuolar forms) & \multicolumn{5}{|c|}{ Medium number \pm standard deviation } \\
\hline G1/10,000 & $0.5 \pm \mathbf{0 . 8}$ & ND & ND & $0.5 \pm 0.5$ & ND \\
\hline G2/5,000 & $1.2 \pm \mathbf{0 . 7}$ & ND & $0.2 \pm \mathbf{0 . 4}$ & $0.5 \pm 1.2$ & ND \\
\hline G3/1,000 & $0.8 \pm \mathbf{0 . 7}$ & $0.2 \pm \mathbf{0 . 4}$ & ND & ND & ND \\
\hline G4/500 & $0.3 \pm \mathbf{0 . 8}$ & $0.2 \pm \mathbf{0 . 4}$ & $1.2 \pm 1.0$ & $0.8 \pm 1.0$ & ND \\
\hline G5/100 & ND & $0.3 \pm \mathbf{0 . 5}$ & $0.2 \pm \mathbf{0 . 4}$ & $0.2 \pm \mathbf{0 . 4}$ & ND \\
\hline
\end{tabular}

$*(p<0.05)=$ vacuolar forms in the $7^{\text {th }}$ day $(10)$ X $60^{\text {th }}$ day (zero) of infection. ND $=$ Not detected. 


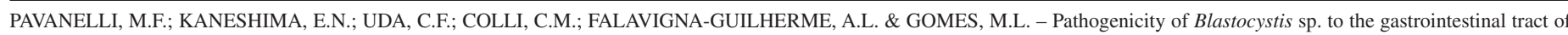
mice: relationship between inoculum size and period of infection. Rev. Inst. Med. Trop. Sao Paulo, 57(6): 467-72, 2015.

Table 3

Relationship between the period of infection, the amount of vacuolar forms inoculated and presence of inflammatory process in the intestinal tract of Swiss mice orally infected

\begin{tabular}{|c|c|c|c|c|c|c|}
\hline Period of infection (days) & 7 & 14 & 21 & 28 & 60 & Total \\
\hline Group/Inoculum (vacuolar forms) & \multicolumn{6}{|c|}{ Medium number of inflammatory process found } \\
\hline G1/10,000 & 2 & 2 & 2 & 1 & 3 & 10 \\
\hline G2/5,000 & 0 & 0 & 1 & 2 & 1 & 4 \\
\hline G3/1,000 & 2 & 0 & 2 & 1 & 1 & 6 \\
\hline G4/500 & 1 & 0 & 5 & 2 & 0 & 8 \\
\hline G5/100 & 1 & 2 & 1 & 1 & 2 & 7 \\
\hline CN & 0 & 0 & 0 & 0 & 0 & 0 \\
\hline Total & 6 & 4 & 11 & 7 & 7 & 35 \\
\hline
\end{tabular}

CN: Negative control.

Table 4

Relationship between the period of infection, the amount of vacuolar forms inoculated and presence of hyperplastic lymphoid aggregates in the intestinal tract of Swiss mice orally infected

\begin{tabular}{|c|c|c|c|c|c|}
\hline Period of infection (days) & 7 & 14 & 21 & 28 & 60 \\
\hline Group/Inoculum (vacuolar forms) & \multicolumn{5}{|c|}{ Rate of hyperplastic lymphoid tissues (\%) } \\
\hline G1/10,000 & 100 & 100 & 0 & 0 & 50 \\
\hline G2/5,000 & 100 & 100 & 0 & 50 & 0 \\
\hline G3/1,000 & 0 & 33.3 & 0 & 0 & 50 \\
\hline G4/500 & 0 & 0 & 100 & 0 & 0 \\
\hline G5/100 & 0 & 66.7 & 0 & 33.3 & 0 \\
\hline CN & 0 & 0 & 0 & 0 & 0 \\
\hline
\end{tabular}

CN: Negative control.

between inoculum size and period of infection and the pathogenicity of Blastocystis sp. in mice. Several authors who have studied the behavior of Blastocystis sp. in other animal models reported histopathological

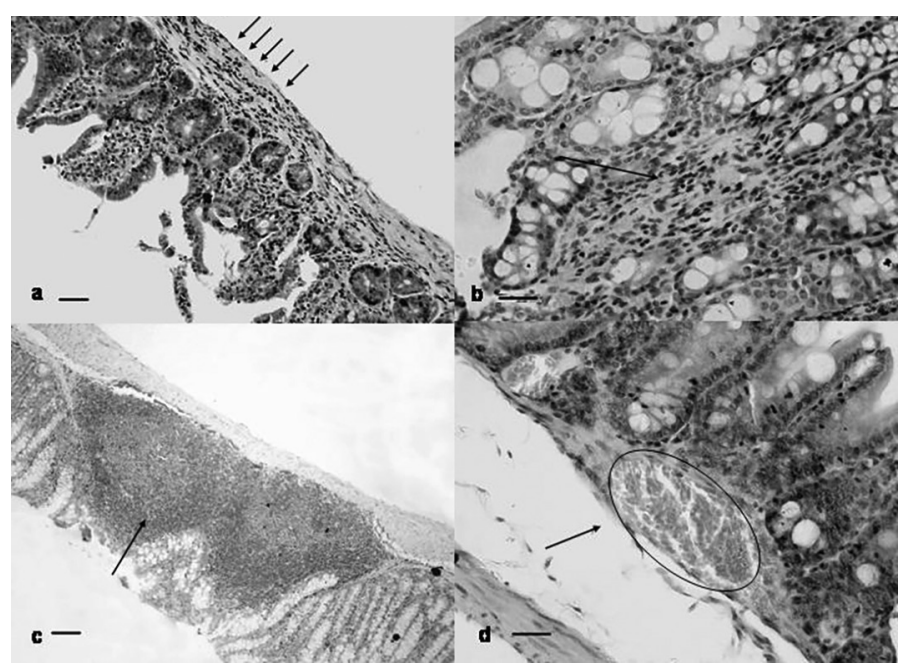

Fig. 2 - a and b) Inflammatory infiltrate with a predominance of mononuclear leukocytes (arrows) in the muscle layer (a) and in the mucosa layer (b), H \& E, duodenum 200X (bar: 150 $\mu \mathrm{m}$ ) and proximal colon 400X (bar: $100 \mu \mathrm{m}$ ), respectively. c) hyperplastic lymphoid aggregate in a large intestine section, $\mathrm{H} \& \mathrm{E}, 100 \mathrm{X}$ (arrow). Bar: $300 \mu \mathrm{m}$. d) Hyperemic vessels (arrow in the circle) in a section of the cecum, $\mathrm{H} \& \mathrm{E}, 400 \mathrm{X}$. Bar: $100 \mu \mathrm{m}$. changes, the local of tissular predilection and inflammatory reactions, without relating their findings with the two variables that were evaluated in this study $5,7,8,23,25,27$.

The quantity of parasitic forms inoculated in the animal has influenced the degree of the inflammatory reaction that was generated because the quantity of released inflammatory mediators was directly proportional to the amount of microrganisms present in the host. These inflammatory mediators are responsible for some of the observed effects in the evaluated tissues: hyperemia, which increases the blood flow to the injured tissue so leukocytes can reach the injured site in order to perform phagocytosis; inflammatory infiltration marked by the presence of leukocytes in the injured site, which arrive there by the action of chemotactic mediators; and hyperplastic lymphoid aggregates that are increased because the mediators of inflammation stimulate the synthesis of lymphocytes (which are stored in the lymphoid aggregates after maturation) so they can "fight" the infectious agent ${ }^{13}$.

In this study, it was possible to infect Swiss mice with Blastocystis sp. with all inocula (100 to 10,000 vacuolar forms), while in another similar study the infection was only possible with inocula containing more than 40 million parasitic forms ${ }^{7}$. Other authors ${ }^{8}$ reported the relationship between the infectivity of different genotypes of Blastocystis sp. and the inocula, in chickens and mice that were challenged with inocula sizes ranging from 100 to $1,000,000$. However, TANIZAKI et al. $(2005)^{23}$ found no infectivity with the 100 vacuolar form inoculum. 


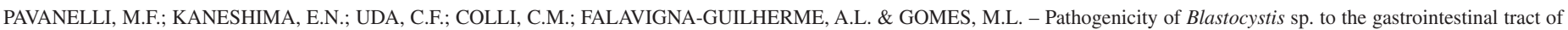
mice: relationship between inoculum size and period of infection. Rev. Inst. Med. Trop. Sao Paulo, 57(6): 467-72, 2015.

According to STENSVOLD et al. (2009) $)^{20}, 10$ different subtypes of Blastocystis sp. (ST1 to 10) have been described, with ST3 being the most common in humans. HUSSEIN et al. $(2008)^{7}$ have studied the pathogenic potential of different genotypes of Blastocystis sp. by evaluating subtypes $1,2,3$ and 4 . ST1 was the most pathogenic, inducing mortality in $25 \%$ of animals, while ST2 showed no significant pathological changes and ST3 and 4 were observed in pathogenic and nonpathogenic strains. Although we have worked with mixed strains belonging to two subtypes considered pathogenic, this situation mimics the infection in humans and this has not influenced our results. Our goal was not only to verify the presence or absence of pathogenicity, but its relationship with inoculum size and duration of infection.

Concerning the period of infection, this study found that $60 \%$ of the animals in the groups G1, G2 and G3 eliminated vacuolar forms in their excreta two days after oral administration of the vacuolar forms, while in the groups G4 and G5 the parasitological exams were positive within seven days of infection. These results showed that the infection was detected earlier in the animals that had received larger inocula, confirming the findings of ELWAKIL \& HEWEDI (2010) $)^{5}$. Regardless of the inoculum administered, vacuolar forms of Blastocystis sp. were not observed in the intestines of animals at 60 days of infection.

The absence of vacuolar forms in tissues at 60 days indicates that the colonization in such animals with the inoculum tested was selflimited, since the cystic forms were also observed in the feces. This fact may be related to the lineage of the animal that is immunocompetent, which was proven by the decrease of inflammatory processes during this period. Our results indicate that infection and colonization occurred in all groups studied since the characteristics of the vacuolar forms used for the infection were different from the forms observed in the feces and remained patent until 28 days, the period in which the vacuolar forms were still observed in tissues. According to HUSSEIN et al. $(2008)^{7}$, rats infected with subtypes 1 to 4 remained infected for a period of 49 days, showing that so far there is no data in the literature that may indicate the fact that a parasite belonging to a particular subtype influences its colonization of the mucosa. As in our study parasites of subtypes 1 and 3 were used, we confirmed the infection of these subtypes, but in our experimental conditions the colonization seems not to have been established for more than 28 days.

Vacuolar forms of Blastocystis sp. were observed in three portions of the intestinal tract, with a predilection for the cecum, followed by the small and large intestine; in the large intestine and cecum, the histopathological changes occurred with higher intensity, confirming the findings of other authors ${ }^{5,26,27}$. Blastocystis sp. was also observed in the different layers of the intestinal tract, and in the large intestine it was visualized invading the muscle layer, showing its pathogenic potential. Animals that presented this invasive form were infected with 5,000 vacuolar forms and were sacrificed on the seventh day of infection. Although there may be not a total correspondence in the course of the infection in animals with the course of infection in human beings, the results presented here show that, at least in animals, the pathogenicity of Blastocystis sp. is related to inoculum size and period of infection, because it is the second largest inoculum and the shortest period of infection that has been analyzed. Such an invasive feature can indicate parasite virulence, since the tissue infiltration usually triggers more intense inflammatory reactions. ELWAKIL \& HEWEDI $(2010)^{5}$ also noted the establishment of the parasite in the muscle layer beyond other pathological changes. Although these authors used a larger inoculum (40 million) and the changes occurred after 14 days of infection, the results support the hypothesis that the pathogenicity of Blastocystis sp. is related to inoculum size and period of infection.

The invasion of the muscle layer increases the chances of occurrence of the extra-intestinal form of the disease, leading to systemic effects. VOGELBERG et al. (2010) ${ }^{24}$ reported a case of generalized hives in a patient with acute diarrhea and a positive parasitological exam for Blastocystis sp. The biopsy revealed the presence of parasitic forms and an inflammatory reaction in the mucosa of the intestinal colon. Other authors also conferred pathogenic potential to this parasite by finding ulcers in the cecum and rectum, acute and chronic inflammation, in addition to parasitic forms of Blastocystis sp. in the muscle layer of the large intestine ${ }^{5,11,27}$. On the other hand, several authors ${ }^{7,9,28}$ have reported that Blastocystis sp. is a nonpathogenic protist, because they did not observe invasive lesions in the intestinal tract of patients, as well as in mice and rats that were orally infected with this parasite. It is possible that these differences are related to different genetic subtypes of the parasite that was involved in each experiment ${ }^{7}$, but also to factors linked to the host as genetics and a prior exposure ${ }^{16}$, as well as inoculum size and period of infection as demonstrated in the present study.

The parasite presence in the tissue is a stimulating factor for the emergence of the inflammatory response in the host. In this study, the implantation of vacuolar forms of Blastocystis sp. in tissues of infected mice, or simply passing through the intestinal tract, were able to trigger the beginning of infection with intense inflammatory infiltrates and a predominance of mononuclear leukocytes and eosinophils, which are characteristic of allergic and parasitic diseases ${ }^{13}$. Other authors ${ }^{5,27}$ have also shown that the inflammatory reaction caused by Blastocystis sp. has some characteristics that differ from traditional reactions, by the finding of monocytes and lymphocytes (mononuclear leukocytes) in the stroma of the ileocecal region from mice orally infected, as these cells are the most commonly found in the case of aggression (infection) in the gut according to ELIA \& SOUZA $(2001)^{4}$.

Hyperplastic lymphoid aggregates were observed in sections with an intense inflammatory reaction, in direct proportion with inoculum size and period of infection in the animals. The presence of hyperplastic lymphoid tissue in the infection by Blastocystis sp. and mainly its relationship with these two variables has not yet been reported by other authors who have studied the infectivity and pathogenicity of this parasite in several animal models ${ }^{2,5,11,24,28}$. These authors described the presence of intense inflammatory exudates (acute and chronic), tissue necrosis and changes in intestinal structure.

It is concluded that Blastocystis sp. has pathogenic characteristics and a short life cycle, and that a low number of vacuolar forms are required to infect the host. In animals, the pathogenicity of this parasite is related to inoculum size, influencing the intensity and number of inflammatory processes, the quantity of hyperplastic lymphoid aggregates and the time when they occurred. It is also concluded that the pathogenicity of Blastocystis sp. is related to period of infection by the earlier occurrence of a larger numbers of vacuolar forms in the tissues and of hyperplastic lymphoid tissues in the evaluated animals. 
PAVANELLI, M.F.; KANESHIMA, E.N.; UDA, C.F.; COLLI, C.M.; FALAVIGNA-GUILHERME, A.L. \& GOMES, M.L. - Pathogenicity of Blastocystis sp. to the gastrointestinal tract of mice: relationship between inoculum size and period of infection. Rev. Inst. Med. Trop. Sao Paulo, 57(6): 467-72, 2015.

\section{RESUMO}

Histopatogenicidade de Blastocystis sp. para o trato gastrointestinal de camundongos: relação com inóculo e tempo de infecção

Pouco é sabido sobre o potencial patogênico de Blastocystis sp. em modelos experimentais. Neste trabalho a patogenicidade desse parasito para o trato gastrointestinal de camundongos Swiss machos foi avaliada de acordo com o inóculo e tempo de infecção. Os animais foram infectados, via intragástrica, com 100, 500, 1.000, 5.000 e 10.000 formas vacuolares de Blastocystis sp. obtidos a partir de uma mistura de oito isolados humanos cultivados axenicamente em meio Jones. Após 7, 14, 21, 28 e 60 dias de infecção os animais foram sacrificados e fragmentos do intestino delgado (duodeno), grosso e ceco foram retirados para análise histopatológica. Blastocystis sp. desencadeou resposta inflamatória nos diferentes tecidos analisados, com predominância de infiltrado mononuclear. No ceco o parasito foi encontrado na túnica muscular mostrando seu caráter invasivo. Inóculos maiores desencadearam processos inflamatórios mais precocemente (7 dias) e inóculos menores mais tardiamente (a partir de 21 dias). Conclui-se que no modelo proposto a patogenicidade dos isolados de Blastocystis sp. estudados tem relação com o inóculo e tempo de infecção.

\section{ACKNOWLEDGMENT}

The authors would like to thank the Post Graduate Support Program (PROAP) from the Coordination for the Improvement of Higher Education Personnel (CAPES) for financial support of this work.

\section{REFERENCES}

1. Amato Neto V, Alarcón RSR, Gakiya E, Bezerra RC, Ferreira CS, Braz LMA. Blastocistose: controvérsias e indefinições. Rev Soc Bras Med Trop. 2003;36:515-7.

2. Andiran N, Acikgoz ZC, Turkay S, Andiran F. Blastocystis hominis: an emerging and imitating cause of acute abdomen in children. J Pediatr Surg. 2006;41:1489-91.

3. Domínguez-Marques MV, Guna R, Muñoz C, Gómez-Muñoz MT, Borrás R. High prevalence of subtype 4 among isolates of Blastocystis hominis from symptomatic patients of a health district of Valencia (Spain). Parasitol Res. 2009;105:949-55.

4. Elia CCS, Souza HSP. Imunologia da mucosa intestinal: da bancada ao leito. São Paulo: Atheneu; 2001

5. Elwakil HS, Hewedi IH. Pathogenic potential of Blastocystis hominis in laboratory mice. Parasitol Res. 2010;107:685-9.

6. Hoffmann WA, Pons JA, Janer JL. The sedimentation concentration method in schistosomiasis mansoni. Puerto Rico J Public Health Trop Med. 1934;9:283-91.

7. Hussein EM, Hussein AM, Eida MM, Atwa MM. Pathophysiological variability of different genotypes of human Blastocystis hominis Egyptian isolates in experimentally infected rats. Parasitol Res. 2008;102:853-60.

8. Iguchi A, Ebisu A, Nagata S, Saitou Y, Yoshikawa H, Iwatani S, et al. Infectivity of different genotypes of human Blastocystis hominis isolates in chickens and rats. Parasitol Int. 2007;56:107-12.

9. Iguchi A, Yoshikawa H, Yamada M, Kimata I, Arizono N. Expression of interferon gamma and proinflammatory cytokines in the cecal mucosa of rats experimentally infected with Blastocystis sp. strain RN94-9. Parasitol Res. 2009;105:135-40.
10. Irikov OA, Antokhin AI, Romanov YA. Study of the dynamics of Blastocystis hominis reproduction in vitro. Bull Exp Biol Med. 2009;148:99-102.

11. Janarthanan S, Khoury N, Antaki F. An unusual case of invasive Blastocystis hominis infection. Endoscopy. 2011;43 (Suppl 2):185-6.

12. Jones WR. The experimental infection of rats with Entamoeba histolytica: with a method for evaluating the anti-amoebic properties of new compounds. Ann Trop Med Parasitol. 1946;40:130-40.

13. Kumar V, Abbas AK, Fausto N, Aster JC. Robbins \& Cotran patologia: bases patológicas das doenças. $8^{\text {a }}$ ed. São Paulo: Elsevier; 2010.

14. Maamouri N, Ben Ayed S, Aoun K, Ben Mami N, Bouratbine A. Prévalence et type des parasitoses associées aux maladies inflammatoires chroniques de l'intestin. Rev Méd Interne. 2011;32S:S313-S434.

15. Macedo HW de, Gonçalves AMH, Almeida CB de, Dias LVB, Muniz MF. Infecção por Blastocystis hominis e Entamoeba histolytica/Entamoeba dispar em pacientes atendidos em um hospital localizado em Niterói, Rio de Janeiro. Rev Patol Trop. 2010;39:56-62.

16. Olivo-Diaz A, Romero-Valdovinos M, Gudiño-Ramirez A, Reyes-Gordillo J, JimenezGonzalez DE, Ramirez-Miranda ME, et al. Findings related to IL-8 and IL-10 gene polymorphisms in a Mexican patient population with irritable bowel syndrome infected with Blastocystis. Parasitol Res. 2012;111:487-91.

17. Parkar U, Traub RJ, Vitali S, Elliot A, Levecke B, Robertson I, et al. Molecular characterization of Blastocystis isolates from zoo animals and their animal-keepers. Vet Parasitol. 2010;169:8-17.

18. Sohail MR, Fischer PR. Blastocystis hominis and travelers. Travel Med Infect Dis. $2005 ; 3: 33-8$

19. Stensvold CR, Smith HV, Nagel RF, Olsen KEP, Traub RJ. Eradication of Blastocystis carriage with antimicrobials: reality or delusion? J Clin Gastroenterol. 2010;44:85-90.

20. Stensvold CR, Nielsen HV, Mølbak K, Smith HV. Pursuing the clinical significance of Blastocystis: diagnostic limitations. Trends Parasitol. 2009;25:23-39.

21. Tan KSW. New insights on classification, identification, and clinical relevance of Blastocystis spp. Clin Microbiol Rev. 2008;21:639-65.

22. Tan TC, Suresh KG. Amoeboid form of Blastocystis hominis: a detailed ultrastructural insight. Parasitol Res. 2006;99:737-42.

23. Tanizaki A, Yoshikawa H, Iwatani S, Kimata I. Infectivity of Blastocystis isolates from chickens, quails and geese in chickens. Parasitol Res. 2005;96:57-61.

24. Vogelberg C, Stensvold CR, Monecke S, Ditzen A, Stopsack K, Heinrich-Gräfe U, et al. Blastocystis sp. subtype 2 detection during recurrence of gastrointestinal and urticarial symptoms. Parasitol Int. 2010;59:469-71.

25. Yoshikawa H, Morimoto K, Nagashima M, Miyamoto N. A survey of Blastocystis infection in anuran and urodele amphibians. Vet Parasitol. 2004;122:91-102a.

26. Yoshikawa H, Yoshida K, Nakajima A, Yamanari K, Iwatani S, Kimata I. Fecaloral transmission of the cyst form of Blastocystis hominis in rats. Parasitol Res. 2004;94:391-6b.

27. Zhang HW, Li W, Yan QY, He LJ, Su YP. Impact of Blastocystis hominis infection on ultrastructure of intestinal mucosa in mice. Zhongguo Ji Sheng Chong Xue Yu Ji Sheng Chong Bing Za Zhi. 2006;24:187-91.

28. Zuckerman MJ, Watts MT, Ho H, Meriano FV. Blastocystis hominis infection and intestinal injury. Am J Med Sci. 1994;308:96-101.

Received: 23 September 2013

Accepted: 26 February 2015 